\title{
Questes
}

\section{Le Petit Artus de Bretagne ou la nuit féconde en romanesque}

Anne-Cécile Le Ribeuz

\section{(2) OpenEdition}

10 Journals

\section{Édition électronique}

URL : http://journals.openedition.org/questes/1869

DOI : 10.4000/questes.1869

ISSN : 2109-9472

Éditeur

Les Amis de Questes

\section{Édition imprimée}

Date de publication : 15 janvier 2004

Pagination : 9-14

ISSN : 2102-7188

\section{Référence électronique}

Anne-Cécile Le Ribeuz, « Le Petit Artus de Bretagne ou la nuit féconde en romanesque », Questes [En ligne], 6 | 2004, mis en ligne le 01 janvier 2014, consulté le 15 septembre 2020. URL : http:// journals.openedition.org/questes/1869

Ce document a été généré automatiquement le 15 septembre 2020.

(c) Association des amis de «Questes » 


\title{
Le Petit Artus de Bretagne ou la nuit féconde en romanesque
}

\author{
Anne-Cécile Le Ribeuz
}

NOTE DE L'ÉDITEUR

Cet article n'a pas encore fait l'objet d'une autorisation de publication.

INDEX

Mots-clés : nuit, courtoisie, rêve, roman, prémonition, danger, astronomie, tombe, métaphore, obscurité, magie, mort

Keywords : night, courtesy, wedding, novel, premonition, dream, astronomy, metaphor, darkness, danger, magic, grave, death 